\title{
Development of phospholipase $\mathrm{A}_{2}$ and lysophosphatidylcholine metabolising enzyme activities in the neonatal rat intestine
}

\author{
C TAgESSON, E TELEMO, G EKSTRÖM AND B WESTRÖM \\ From the Department of Occupational Medicine and Department of Clinical Chemistry, Linköping University, \\ Linköping, and Department of Zoophysiology, University of Lund, Lund, Sweden
}

SUMmary We have studied the development of phospholipase $\mathrm{A}_{2}\left(\mathrm{PLA}_{2}\right)$ and lysophosphatidylcholine (lysoPC)-metabolising enzyme activities in the neonatal rat intestine and its relation to the intestinal permeability of macromolecules. The permeability was determined by feeding young rats a mixture of bovine serum albumin, bovine immunoglobulin $G$ and fluorescein-isothiocyanateconjugated dextran 70000 , and analysing the serum concentrations after six hours. The animals were then killed and the intestinal mucosa was homogenised and assessed for PLA $\mathrm{A}_{2}$ and lysoPCmetabolising enzyme activities. The intestine was 'open' to the macromolecules in 14 day old animals, but 'closed' in 22 and 32 day old animals and in 14 day old rats treated with cortisone acetate on day 10,11 , and 12 postpartum. The activity of $\mathrm{PLA}_{2}\left(\right.$ at $\mathrm{pH} 6$ and $2 \mathrm{mM} \mathrm{Ca}^{2+}$ ) was higher in 32,22 , and cortisone treated 14 day old animals, than in untreated, 14 day old animals. Incubation of ${ }^{14} \mathrm{C}$-acyl-lysoPC with mucosa from 14 day old rats did not change the radioactivity pattern as shown by thin layer chromatography, whereas after incubation with mucosa from 22 or 32 day old animals all the radiolabel was found in free ${ }^{14} \mathrm{C}$-fatty acid and in ${ }^{14} \mathrm{C}$-phosphatidylcholine. These findings indicate that mucosal PLA $\mathrm{P}_{2}$ activity increases during intestinal maturation and that the mucosa acquires the ability to acylate and deacylate lysoPC when it is 'closed' to macromolecules.

The rat intestine is relatively immature at birth and for the first postnatal weeks. During the third week and coordinated with the weaning process, however, it undergoes a dramatic array of biochemical and functional adaptations.' Mucosal lactase activity declines and the intestinal hydrolases that are involved in the digestion of solid food carbohydrates appear and increase considerably in activity. ${ }^{2}$ Concomitantly, other hydrolytic enzymes show distinct developmental patterns. Alkaline phosphatase shows a marked increase in activity during the third week of life in rats and mice,,$^{3+}$ and many lysosomal enzymes have high activities in the rat intestine during the first postnatal weeks but decrease during the third week.' Altogether, these ontogenetic changes seem correlated with the occurrence of a more adult type of enterocytes during the third week of life in the rat. ${ }^{5}$

Address for correspondence: C Tagesson. Department of Occupational Medicinc. Linköping University, S-581 85 Linköping. Sweden

Received for publication 3 October, 1986.
In this paper we report some observations concerning the development of phospholipase $\mathrm{A}_{2}\left(\mathrm{PLA}_{2}\right)$ and lysophosphatidylcholine (lysoPC)-metabolising enzyme activities in the neonatal rat intestine. These enzymes are ubiquitously present in living organisms and the action of $\mathrm{PLA}_{2}$ and the formation of lysoPC has been implicated in the regulatory and effect functions in a variety of cells. ${ }^{6-11}$ Phospholipid metabolising enzymes have also been found in the mucosal cells of the small intestine $e^{12-14}$ although their localisation, properties and function in these cells have been examined only to a limited extent. Apparently, $\mathrm{PLA}_{2}$ and lysoPC-metabolising enzymes are involved in the digestion and absorption of diacylphosphoglycerides in the adult, ${ }^{12-1.3}$ but little is known about developmental changes in the newborn that might parallel dietary changes, changes in the intestinal microbial flora, or changes in the intestinal permeability. Moreover, as $\mathrm{PLA}_{2}$ releases arachidonic acid from phospholipids and may thus regulate the synthesis of prostaglandins, ${ }^{15}$ the activity of PLA 2 
in the developing intestine is of considerable importance. ${ }^{16}$

We have thus determined $\mathrm{PLA}_{2}$ and lysoPCmetabolising enzyme activities during intestinal development in the rat. In particular, we have tried to relate the development of these activities to the intestinal permeability to macromolecules. This is not only because the rat intestine undergoes a dramatic decrease in macromolecular permeability during the third week of postnatal development, ${ }^{5}$ but also because lysoPC apparently increases ileal permeability to macromolecules in the adult rat. ${ }^{17}$ Our findings indicate that intestinal PLA $_{2}$ activity is increased during maturation, and that the mucosa acquires the ability to acylate and deacylate lysoPC when it is 'closed' for macromolecules.

\section{Methods}

\section{A N I M A LS}

Normally suckled litters of Sprague-Dawley rats, bred in our own laboratory under standard conditions, were used. The siblings of three litters were divided in age groups and used 14,22 , and 30 days postpartum. The young rats were separated from their dams, placed in heated cages, and starved two hours before experimentation.

To induce intestinal macromolecular closure when tested at day 14 postpartum, half of the rats in two litters ( $n=6$ and $n=10$, respectively) were given daily ip injections of $2.5 \mathrm{mg}$ cortisone ace tate (Sigma Chemical Company, St Louis, Missouri, USA), dissolved in $0.9 \%$ saline, on day 10,11 , and $12 .{ }^{16-211}$ The other half of each litter served as controls and were treated the same way but given $0.9 \%$ saline.

\section{ADMINISTRATION OF INTESTINAL PERMEABILITY MARKERS}

The rats were fed a marker solution containing bovine serum albumin (BSA, fraction V; Sigma), bovine gammaglobulin (B-IgG, Cohn fraction II, Sigma), and fluoresceinisothiocyanate labelled dextran with a mean molecular weight of 70000 daltons (FITC-D 70000, Sigma), $30 \mathrm{mg} / \mathrm{ml}$ of each, dissolved in $0.9 \%$ saline. All rats were fed $0.05 \mathrm{ml} / \mathrm{g}$ body weight of the marker solution, intragastrically through a stomach tube. After feeding, the rats were kept separated from their dams for six more hours. They were then killed and blood samples taken to determine intestinal permeability.

\section{SAMPLING}

Blood samples were collected by heart puncture and were allowed to clot at room temperature for 15 minutes before serum was harvested. Immediately after death, the abdomen was opened and the small intestine was gently stripped off the mesenterery and divided in two portions of equal length, one proximal and one distal. The contents of each intestinal portion was flushed out with ice cold saline. The intestine was then opened longitudinally, and the intestinal epithelium was scraped off with a microscope slide. Precaution was taken to remove only the superficial layers of the mucosa. The tissue was then suspended in ice cold $150 \mathrm{mM} \mathrm{NaCl}$ and disintegrated by 10 strokes in a glass homogeniser with the use of a tight fitting pestle. All samples were stored at $-20^{\circ} \mathrm{C}$ until analysed.

ANALYSIS OF PERMEABILITY MARKERS IN BIOOOD SERUM

Quantification of BSA in all serum samples was done by electroimmunoassay"1 using crystallised and lyophilised BSA (article A 7638 from Sigma) as standard. Specific antisera to BSA was obtained from Miles Laboratories (Freehold, NJ USA). B-IgG was estimated using single radial immunodiffusion ${ }^{22}$ using purified B-IgG (G-3500 from Sigma) as standard and specific antisera from Miles. FITC-D 70000 was analysed by fluorescence spectrometry as described elsewhere. ${ }^{23}$

DETERMINATION OF MU COSAL PLA 2 ACTIVITY

Phospholipase $A_{2}$ activity was assayed with the use of ${ }^{14} \mathrm{C}$-oleate-labelled $E$ coli as substrate ${ }^{24}$ and with a $0.45 \mu \mathrm{m}$ Millipore filter to separate the product of hydrolysis-the ${ }^{14} \mathrm{C}$-oleic acid-from the unhydrolysed substrate. ${ }^{25}$ The reaction mixtures contained 7000 cpm ${ }^{14} \mathrm{C}$-oleate-labelled $E$ coli, $2 \mathrm{mM} \mathrm{CaCl}, 100 \mu \mathrm{l}$ homogenised mucosal cells (1-8 $\mu$ g Lowry protein) and $300 \mu \mathrm{l}$ buffer of suitable $\mathrm{pH}(\mathrm{pH} 2-5$ citrate (240-450 mM) - phosphate (50-260 mM), pH 6-8 Tris-maleate $(100 \mathrm{mM})$, and $\mathrm{pH} 9-10$ glycine- $\mathrm{NaOH}$ $(50 \mathrm{mM}))$. The mixtures were incubated at $37^{\circ} \mathrm{C}$ for $90 \mathrm{~min}$ and the reactions stopped by adding $2 \mathrm{ml}$ ice cold $150 \mathrm{mM} \mathrm{NaCl}$ with $1 \% \mathrm{BSA}$. After filtration through a Millipore $0.45 \mu \mathrm{m}$ filter, the radioactivity in the filtrate was counted and expressed as percent of total radioactivity in the bacteria $(1 \%$ radioactivity per $\mu$ g protein $=1$ unit PLA $_{2}$ ).

\section{DEMONSTRATION OF LYSOPC-METABOIISING} ENZYME ACTIVITIES

Lysophosphalidylcholine (article L 4129 from Sigma) and ${ }^{1+} \mathrm{C}$-lysoPC (from New England Nuclear, Dreieichenheim, West Germany) were incubated with homogenised ileal mucosa from 14,22 , and 32 day old rats, and the reaction products were analysed by thin layer chromatography. The reaction mixtures contained, in a final volume of $500 \mu 1$, $5 \mathrm{mM}$ lysoPC, $20000 \mathrm{cpm}{ }^{14} \mathrm{C}$-lysoPC, 100)-800 $\mu \mathrm{g}$ homogenised mucosa, and $80 \mathrm{mM}$ Tris-maleate. 
Table 1 Intestinal permeability to BSA, B-IgG, and FITCdextran 70000 (FITC-D), measured as the serum concentrations 6 hours after test feeding normal, rats of different ages. Values are means $\pm S E M$; number of animals analysed are indicated within parenthesis.

\begin{tabular}{llll}
\hline \multirow{3}{*}{$\begin{array}{l}\text { Age } \\
\text { (days) }\end{array}$} & \multicolumn{3}{l}{ Blood serum concentration $(\mu g / m l)$} \\
\cline { 2 - 3 } & $B S A$ & $B-\lg G$ & FITC-D \\
\hline $14(\mathrm{n}=6)$ & $21 \pm 3$ & $577 \pm 52$ & $3 \cdot 3 \pm 1 \cdot 2$ \\
$22(\mathrm{n}=6)$ & $1 \pm 1$ & $\mathrm{ND}^{*}$ & $0 \cdot 8 \pm 0 \cdot 1$ \\
$32(\mathrm{n}=8)$ & $2 \pm 1$ & ND & $0 \cdot 4 \pm 0 \cdot 1$ \\
\hline
\end{tabular}

${ }^{*} \mathrm{ND}=$ not detectable $(<3 \mu \mathrm{g} / \mathrm{ml})$.

$\mathrm{pH} 7 \cdot 2$. The mixtures were incubated under shaking in a water bath at $37^{\circ} \mathrm{C}$ for $60 \mathrm{~min}$. The reactions were then stopped and the mixtures extracted with $3 \mathrm{ml}$ chloroform-methanol (1:2). After addition of $1.5 \mathrm{ml}$ $\mathrm{KC1}$ and $1 \mathrm{ml}$ chloroform, each mixture was centrifuged $(500 \mathrm{~g}, 10 \mathrm{~min})$ to facilitate phase separation. The water methanolic phase was washed with $2 \mathrm{ml}$ chloroform, and the combined organic phase was dried under nitrogen. The residue was then redissolved in $200 \mu \mathrm{l}$ chloroform-methanol $(2: 1)$ and transferred onto thin layer plates (Silica gel ready plates, Schleicher-Schull, GmbH, West Germany). Chromatography was carried out in chloroform: methanol: water $(75: 25: 4)$ for three hours at $+4^{\circ} \mathrm{C}$. The radioactivity pattern was then analysed on a TLC-scanning instrument (Dunnschicht Scanner II, LB 2723: Berthold, Kebo-Grave Labcenter AB, Stockholm, Sweden).

\section{STATISTICAL ANALYSIS}

Statistical significance was assessed using Student's $t$ test.

\section{Results}

INTESTINAL PERMEABILITY BEFORE AND AFTER CLOSURE

The permeability to BSA, B-IgG, and FITC-dextran 70000 in untreated rats of different ages is shown in Table 1. It thus appeared that the intestine of 14 day old rats allowed large amounts of the macromolecules to pass through, whereas the intestine of 22 (and 32) day old rats did not. It also appeared that in cortisone treated 14 day old rats, only inconspicious amounts of the macromolecules were let through the

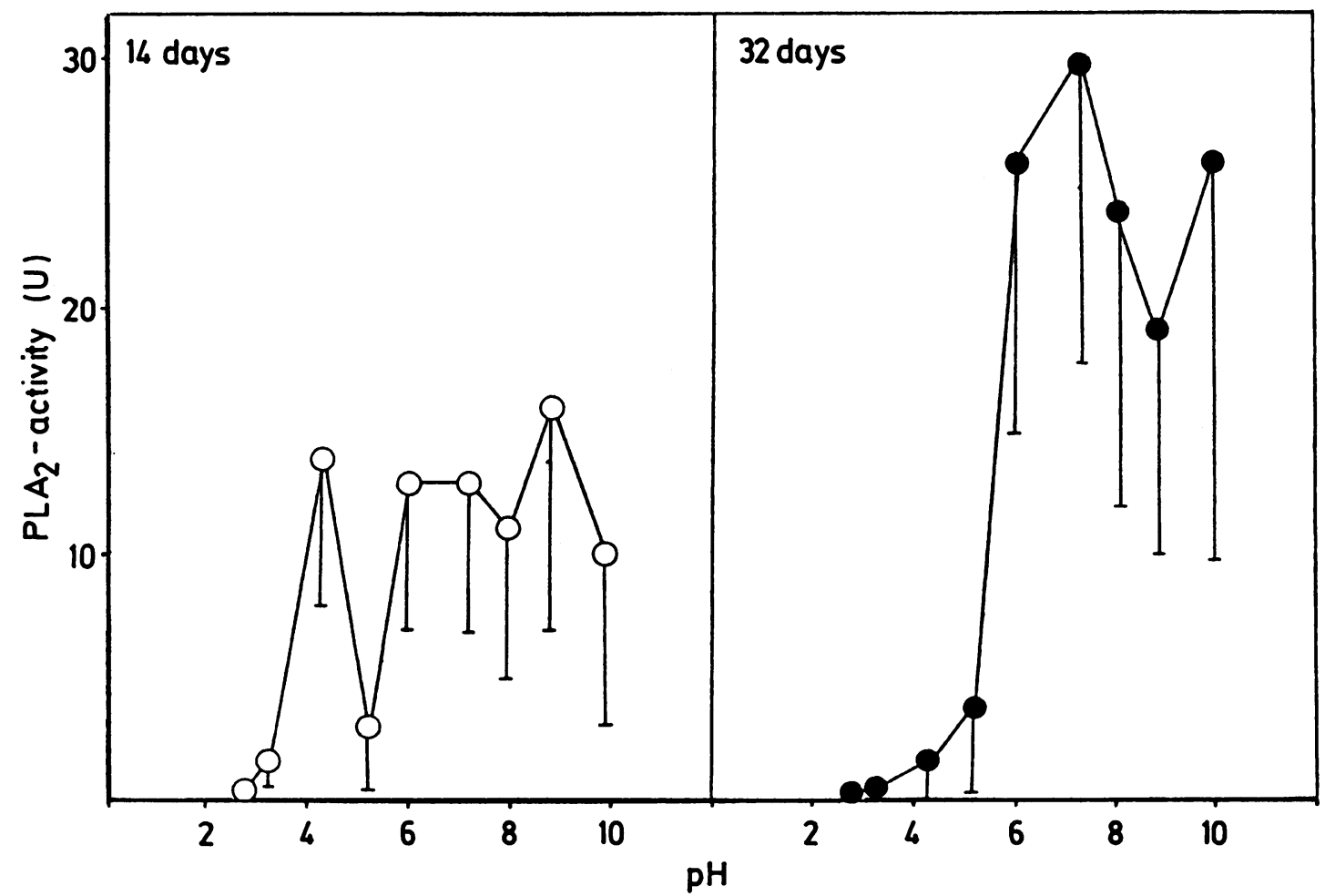

Fig. $1 P L A_{2}$ activity at various $p H$ values in homogenised ileal mucosa from different-aged rats (left: 14 days, right: 32 days). Mean of three experiments, vertical bar indicates one standard deviation. 
Table 2 Intestinal permeability to $B S A, B-\operatorname{Ig} G$, and FITCdextran 70000 (FITC-D), measured as the serum concentrations 6 hours after test feeding cortisone treated and control rats. Values are means $\pm S E M$ of eight animals analysed in each group.

\begin{tabular}{llcl}
\hline \multirow{2}{*}{ Animals } & \multicolumn{2}{l}{ Blood serum concentration $(\mu g / m l)$} & \\
\cline { 2 - 3 } & $B S A$ & $B-I g G$ & FITC-D \\
\hline Controls & $21 \pm 1$ & $518 \pm 21$ & $4 \cdot 3 \pm 1 \cdot 0$ \\
Cortisone-treated & ND $^{*}$ & $4 \pm 0 \cdot 4$ & $0 \cdot 4 \pm 0 \cdot 1$ \\
\hline
\end{tabular}

${ }^{*} \mathrm{ND}=$ not detectable $(<1 \mu \mathrm{g} / \mathrm{ml})$.

intestine as compared with the passage in untreated rats of that same age (Table 2).

PLA 2 ACTIVITY BEFORE AND AFTER CLOSURE The activity of $\mathrm{PLA}_{2}$ in intestinal mucosa from rats of different ages is illustrated in Figure 1 and in Table 3. Activity was found in a broad $\mathrm{pH}$ range in 14 day old rats (Fig. 1, left), whereas the activity in 32 day old rats was most prominent at $\mathrm{pH} \mathrm{6-10} \mathrm{(Fig.} \mathrm{1,} \mathrm{right).}$ Activity at pH 4 was evident in 14 day old animals but very low in 32 day old animals. At pH 6, the $\mathrm{PLA}_{2}$ activity in the distal small gut mucosa was $22 \pm 3.7$ units $(M \pm S E M, n=12)$ in 32 day old rats, but only $5.3 \pm 0.9$ units in 14 day old rats $(p<0.001)$. In the proximal small gut mucosa, the $\mathrm{PLA}_{2}$ activity was
Table $3 \quad \mathrm{PLA}_{2}$ activity (at $\mathrm{pH} 6$ and $2 \mathrm{mM} \mathrm{Ca}^{2+}$ ) in homogenised intestinal mucosa of rats of different ages. Values are means $\pm S E M$; number of animals analysed are indicated within parenthesis.

\begin{tabular}{lll}
\hline $\begin{array}{l}\text { Age } \\
\text { (days) }\end{array}$ & $P L A_{2}$ activity (units)* & \\
\cline { 2 - 3 } & Proximal gut & Distal gut \\
\hline 14 & $1 \cdot 6 \pm 0 \cdot 6(12)$ & $5 \cdot 3 \pm 0.9(12)$ \\
22 & $4 \cdot 4 \pm 1 \cdot 2(11)$ & $6 \cdot 7 \pm 0 \cdot 4(11)$ \\
32 & $3.7 \pm 1 \cdot 5(12)$ & $22 \pm 3 \cdot 7(12)$ \\
\hline
\end{tabular}

*\% radioactivity in filtratc/ $\mu \mathrm{g}$ protcin.

$4 \cdot 4 \pm 1 \cdot 2$ units in 22 day old rats, but only $1 \cdot 6 \pm 0 \cdot 6$ units in 14 day-old rats $(p<0 \cdot 05)$.

The PLA $\mathrm{P}_{2}$ activity in mucosal cells from cortisone treated 14 day old animals is illustrated in Figure 2 and Table 4. As compared with the activity in untreated animals (Fig. 2, left), the activity in cortisone treated was more prominent at $\mathrm{pH}$ 6-7 and less prominent at $\mathrm{pH} \mathrm{4-5} \mathrm{(Fig.} \mathrm{2,} \mathrm{right).} \mathrm{At} \mathrm{pH} 6$, the activity in cortisone treated animals were higher than in untreated, both in the proximal $(p<0.05)$ and in the distal gut mucosa $(\mathrm{p}<0.001)$.

LYSOPC-METABOLISING CAPACITY BEFORE AND AFTER CLOSURE

The metabolism of lysoPC by homogenised ileal

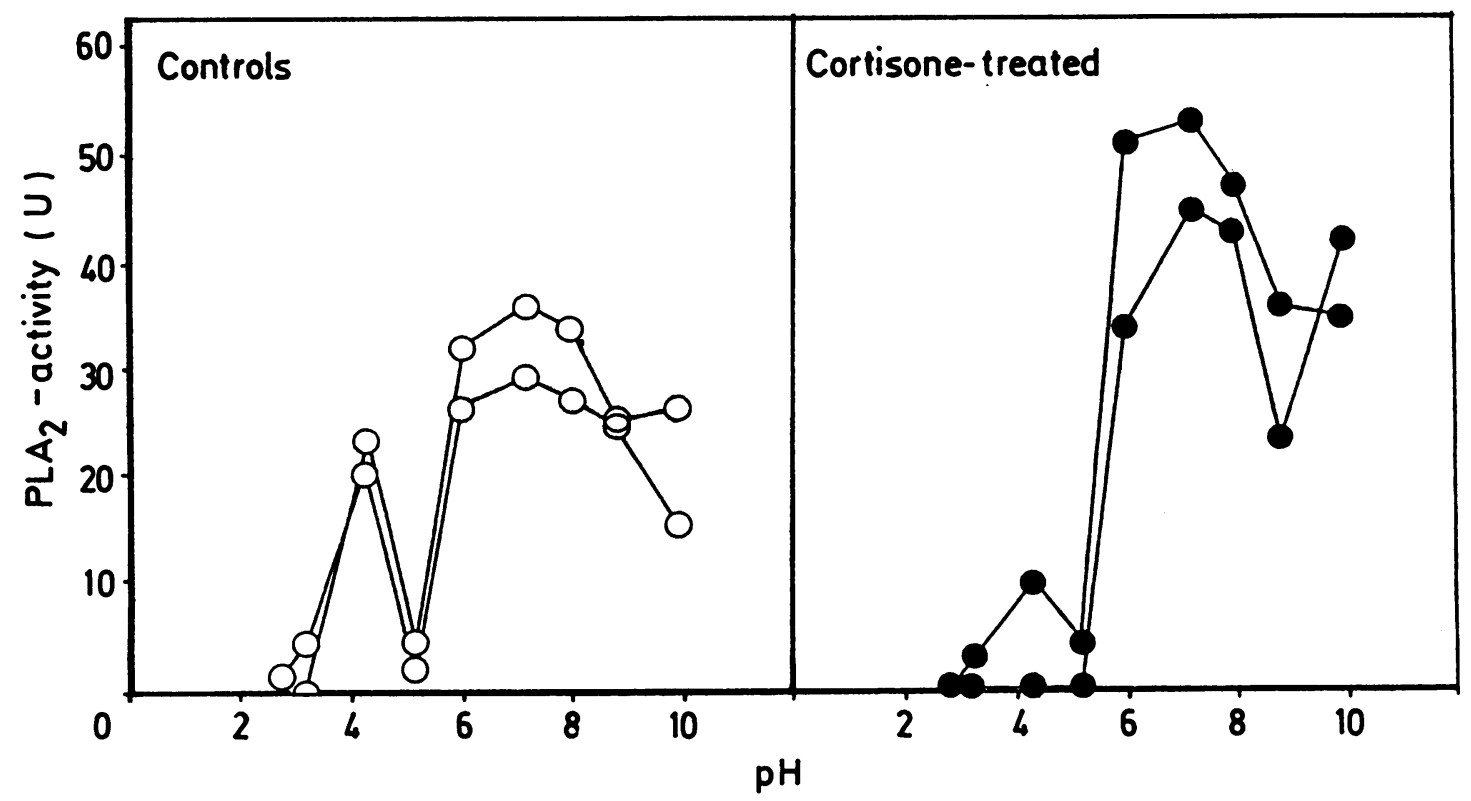

Fig. $2 P L A_{2}$ activity at various $\mathrm{pH}$ values in homogenised ileal mucosa from 14 day old rats treated with cortisone (right) or saline (left). Each curve represents the activity in a homogenate obtained by pooling cells from rats in two different litters ( $n=6$ and $n=10$, respectively). Half of the rats in each litter $(n=3$ and $n=5$, respectively) were treated with cortisone whereas the others were given saline. 
Table 4 PLA, activity (at pH 6 and $2 \mathrm{mMCa}^{2+}$ ) in homogenised intestinal mucosa of cortisone treated and control rats. Values are means $\pm S E M$ of eight animals analysed in each group.

\begin{tabular}{lll}
\hline & \multicolumn{2}{c}{$P L A_{2}$ activity $($ units) } \\
Animals & Proximal gut & Distal gut \\
\hline Controls & $1 \cdot 8 \pm 0 \cdot 3$ & $2 \cdot 4 \pm 0 \cdot 2$ \\
Cortisone treated & $5 \cdot 1 \pm 1 \cdot 3$ & $6 \cdot 5 \pm 0 \cdot 6$ \\
\hline
\end{tabular}

$* \%$ radioactivity in filtrate/ $\mu \mathrm{g}$ protcin.

mucosa of different aged rats is illustrated in Figure 3. Thus, incubation of ${ }^{14} \mathrm{C}$-acyl-lysoPC with cells from 14 day old rats did not change the radioactivity pattern as shown by TLC, whereas after incubation with cells from 22 or 32 day old rats, all the radiolabel was found in free ${ }^{14} \mathrm{C}$-fatty acid and in ${ }^{14} \mathrm{C}$ phosphatidylcholine (PC). The ${ }^{14} \mathrm{C}$-acyl-lysoPC was thus both deacylated (to form free ${ }^{14} \mathrm{C}$-fatty acid) and acylated (to form ${ }^{1+} \mathrm{C}-\mathrm{PC}$ ).

\section{Discussion}

The present investigation indicates that mucosal $\mathrm{PLA}_{2}$ activity increases during intestinal maturation. Thus, the PLA $\mathrm{P}_{2}$ activity (at $\mathrm{pH} 6$ and $\mathrm{mM} \mathrm{Ca}^{2+}$ ) was higher in 22 and 32 than in 14 day old rats (Table 3 ), and it was also higher in cortisone treated than in untreated 14 day old animals (Table 4). As illustrated in Tables 1 and 2, respectively, the intestine was open to macromolecules in 14 day old rats, but closed both in 22 and 32 day old rats and in 14 day old rats that had been given cortisone. These findings, therefore, suggest that mucosal $\mathrm{PLA}_{2}$ activity (at $\mathrm{pH}$ 6) is increased after macromolecular closure. This appears to be the case whether the closure is occurring naturally or is induced by cortisone. Indeed, much the same changes occurred in these two cases, both with regard to macromolecular permeability (Table 1 and Table 2) and PLA $_{2}$ development (Figs 1, 2).

The investigation also shows that homogenised mucosal cells from 14 day old rats do not metabolise lysoPC in vitro, whereas cells from 22 or 32 day old rats do. Thus, after incubation with cells from 22 day old rats, all the lysoPC was transferred into PC and free fatty acid (Fig. 3). Because the intestine was 'open' to macromolecules in 14 day old but 'closed' in 22 day old rats, it can be assumed that the mature intestinal mucosa, as opposed to the immature, has the ability to acylate and deacylate lysoPC.

There is, therefore, some indication that mucosal $\mathrm{PLA}_{2}$ activity increases during intestinal maturation, and that the intestinal mucosa acquires the ability to acylate and deacylate lysoPC when it is 'closed' for macromolecules. The biological implication of these
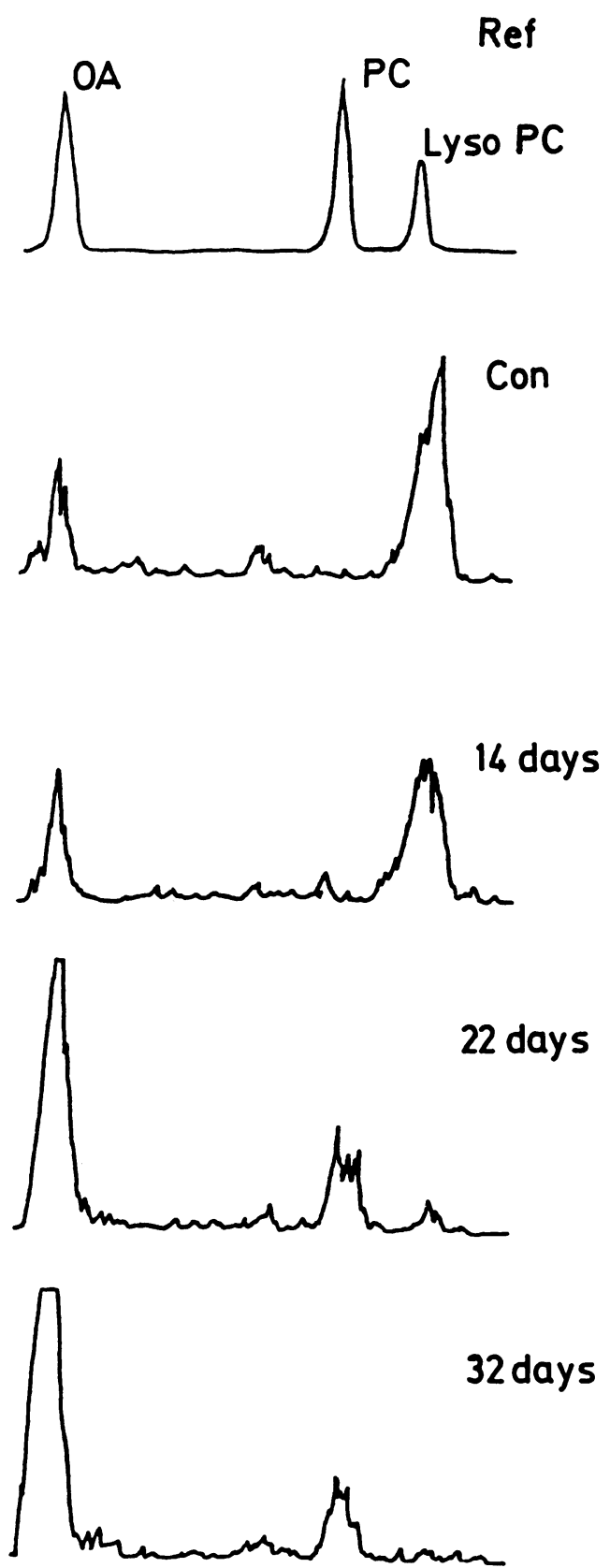

Fig. 3 Metabolism of lysoPC by homogenised ileal mucosa from rats of different ages. The top panel (Ref) shows TLC of reference substances (lyso $P C=$ lysophosphatidylcholine, $P C=$ phosphatidylcholine, $O A=$ oleic acid), whereas Con shows the TLC pattern of lysoPC alone-that is, after incubation of lysoPC in the absence of mucosa. The lower panels show the TLC patterns after incubation of lysoPC with ileal mucosa of rats of different ages (14 days, 22 days, and 32 days, respectively). 
findings is unclear. It is possible that the increase in $\mathrm{PLA}_{2}$ activity reflects a physiological adaption to dietary changes or alterations in the gut microbial flora, or that the mature gut mucosa is equipped with higher PLA $_{2}$ activity for the liberation of arachidonic acid and eventual prostaglandin synthesis. Accordingly, the development of lysoPCmetabolising enzymes could be linked to this increase in PLA $_{2}$ activity. As lysoPC increases the intestinal permeability to macromolecules in the adult rat, ${ }^{17}$ and increased intestinal absorption of macromolecules may be of critical importance to the pathogenesis of many diseases, ${ }^{26}$ there are, teleologically, good reasons for the mature gut mucosa to have lysoPCmetabolising enzyme activities.

On the other hand, the neonatal mucosa is quite permeable to macromolecules under physiological conditions so that large quantities of antibodies and antigens may be transported across the mucosa into the systemic circulation. It can be hypothesised that during this period, the mucosa would be less contingent on the ability to metabolise lysoPC, but that it would have to acquire the lysoPC-metabolising capacity along with the closure to macromolecular passage. Although we have not substantiated the relevance of this possibility to the development of intestinal disease states, attention is drawn to the recent finding that the ileal mucosa from patients with Crohn's disease, appears to have decreased lysophospholipase and increased PLA $\mathrm{P}_{2}$ activity. ${ }^{27} \mathrm{It}$ is thus possible that the formation and metabolism of lysoPC may be related not only to intestinal permeability in the newborn but also to intestinal disease in the adult. This possibility is now being further investigated.

This work was supported by grant B85-17X-0598305C from the Swedish Medical Research Council.

\section{References}

1 Henning SJ. Postnatal development: coordination of feeding, digestion and metabolism. Am J Physiol 1981; 241: $199-214$.

2 Henning SJ. Hormonal and dietary regulation of intestinal enzyme development. In: Miller CM, ed. Intestinal toxicology. New York: Raven Press, 1984: 17-32.

3 Deren JJ. Development of intestinal structure and function. In: Code CF, ed. Handbook of physiology. Section 6. Alimentary canal. Vol 3: Intestinal absorption. Washington DC: American Physiological Society, 1968: 1099-123.

4 Moog F. Corticoids and the enzymic maturation of the intestinal surface: alkaline phosphatase, leucyl naphthylamidase and sucrase. In: Hamburgh $M$, Barrington
EJW, eds. Hormones in development. New York: Meredith, 1971: 143-60.

5 MacKenzie N. $F_{c}$-receptor-mediated transport of immunoglobulin across the intestinal epithelium of the neonatal rodent. Immunol Today 1984; 5: 364-6.

6 Hirata F, Korkoran BA, Venkatsobramanjan K, Schiffman E, Axelrod J. Chemoattractants stimulate degradation of methylated phospholipids and release of arachidonic acid in rabbit leukocytes. Proc Natl Acad Sci USA 1979; 76: 2640-3.

7 Hirata F, Toyoshima S, Axelrod J, Waxdal MJ. Phospholipid methylation: a biochemical signal modulating lymphocyte mitogenesis. Proc Natl Acad Sci USA 1980; 77: 862-5.

8 Hoffman T, Hirata F, Bougnoux P, et al. Phospholipid methylation and phospholipase $\mathrm{A}_{2}$ activation in cytotoxicity by human natural killer cells. Proc Natl Acad Sci USA 1981; 78: 3839-43.

9 Bareis DL, Hirata F, Schiffman E, Axelrod J. Phospholipid metabolism, calcium flux, and the receptormediated induction of chemotoxis in rabbit neutrophils. J Cell Biol 1982; 93: 690-7.

10 Hong SL, Deykin D. The activation of phosphatidylinositol-hydrolyzing phospholipase $\mathrm{A}_{2}$ during prostaglandin synthesis in transformed mouse BALB/3T3 cells. J Biol Chem 1981; 256: 5215-9.

11 Weltzien HU. Cytolytic and membrane-perturbing properties of lysophosphatidylcholine. Biochim Biophys Acta 1979; 559: 259-87.

12 Patton JS. Gastrointestinal lipid digestion. In: Johnson LR, ed. Physiology of the gastrointestinal tract. New York: Raven Press, 1981: 1123-46.

13 Thomson ABR, Dietschy JM. Intestinal lipid absorption: major extracellular and intracellular events. In: Johnson LR, ed. Physiology of the gastrointestinal tract. New York: Raven Press, 1981: 1147-220.

14 Tagesson C, Sjödahl R. Studies of the phospholipase $A_{2}$ activity of rat ileal mucosa. Scand J Gastroenterol 1985; 20: $25-30$.

15 Kunze H, Vogt W. Significance of phospholipase $A_{2}$ for prostaglandin synthesis. Ann NY Acad Sci 1971; 180: 123-5.

16 Lee JB. In: Williams RW, ed. Textbook of endocrinology. Philadelphia, Pa: Saunders, 1974: 854-68.

17 Tagesson C, Franzen L, Dahl G, Weström B. Lysophosphatidylcholine increases rat ileal permeability to macromolecules. Gut 1985; 26: 369-77.

18 Halliday R. The effect of steroid hormones on the absorption of antibodies by the young rat. $J$ Endocrinol 1959; 18: 56-66.

19 Jones RE. Intestinal absorption and gastrointestinal digestion of protein in the young rat during the normal and cortisone induced post closure period. Biochim Biophys Acta 1972; 274: 412-9.

20 Morris B, Morris R. Globulin transmission by the gut of the young rat and the effects of cortisone acetate. In: Hemmings ed. Materno-fetal transmission of immunoglobulins. London: Cambridge University Press, 1975: 359-68.

21 Laurell CB. Quantitative estimation of proteins by electrophoresis in agarose gel containing antibodies. Anal Biochem 1966; 15: 45-52. 
22 Fahey LL, McKelvey EM. Quantitative determination of serum immunoglobulins in agar plates. $J$ Immunol 1965; 94: 84-90.

23 Weström BR, Svendsen J, Ohlsson BG, Tagesson C, Karlsson BW. Intestinal transmission of macromolecules (BSA and FITC-labelled dextrans) in the neonatal pig: influence of age of piglet and molecular weight of markers. Biol Neonate 1984; 46: 20-6.

24 Patriarca P, Beckerdite S, Elsbach P. Phospholipases and phospholipid turnover in Escherischia coli spheroplasts. Biochim Biophys Acta 1972; 260:
593-600.

25 Vadas P, Hay JB. The release of phospholipase $\mathrm{A}_{2}$ from aggregated platelets and stimulated macrophages of sheep. Life Sci 1980; 26: 1721-9.

26 Tagesson $\mathrm{C}$, Magnusson KE, Sundqvist $\mathrm{T}$. Intestinal permeability studies and human disease. Monogr Allergy 1981; 17: 250-72.

27 Bolin T, Heuman R, Sjödahl R, Tagesson C. Decreased lysophospholipase and increased phospholipase $\mathrm{A}_{2}$ activity in ileal mucosa from patients with Crohn's disease. Digestion 1984; 29: 55-9. 